\title{
Ecological, Cultural and Participation (ECP) Method for the Development of Ecotourism Planning and Management Strategies: Example of Ugursuyu and Aksu Basins
}

\author{
Pınar GÜLTEKINN ${ }^{1}$ ，Osman UZUN²
}

\begin{abstract}
:
The study area consists of the $639 \mathrm{~km} 2$ of the Ugursuyu and Aksu watersheds are located midway between the cities of Istanbul and Ankara. Thus, due to their the amenable climate, abundant natural resources and natural setting, rich historical background, provincial lifestyle customs and proximity to metropolitan centers, these sites offer a wealth of opportunity for a variety of eco-tourism activities.

The basic purposes of the study were to combine natural, cultural and social data, to develop ecotourism-centered rural development strategies after analyses and syntheses, to make landscape planning decisions and to develop an ecotourism management model for the ecosystems within the landscapes of the study area. In the study, a three-step method was implemented. In the first step, an inventory and database regarding the area were gathered. Information such as the climatic conditions, soil, geology, hydrology, flora, fauna, socio-economic structure, village settlements, agriculture, forestry, tourism etc. were transferred into the digital medium through Geographical Information System (GIS), and a valid database was created in the ArcGIS 9.3 program.

In the second step, in order to identify the potential of ecotourism, a joint assessment was made by employing the environmental corridor method, the ecotourism opportunities spectrum (ECOS) method and cultural landscape analysis. In the third step, an evaluation was carried out covering the ecotourism potential of the area and the residential units. A visual landscape analysis was based on assessments by both experts and users. The changes in landscape patterns and habitat functions were then determined using related methods. In addition, collaborative ecotourism planning was carried out by conducting a survey of the stakeholders to ensure stakeholder cooperation and input.

As a result of related analyses and assessments, a landscape plan was prepared for the project area and strategies that were developed for an ecotourism-centered rural development model was proposed.
\end{abstract}

Keywords: Aksu, Ecotourism, Management, Participation, Rural Development, Landscape Planning, Ugursuyu

\section{Introduction}

In recent years it is aimed to evaluate the social, economic and ecological objectives together in spatial planning studies carried out (Herrmann and Osinski 1999; Leitão and Ahern 2002; Yu and NG 2007; Pickett et al. 2008).Especially in rural areas different analyses and criteria are used together in planning and management studies for tourism or ecotourism in spatial planning (Fung and Wong 2007; De Groot et al. 2010; Koschke et al. 2012; Tassinari et al. 2013). One of the most important tools in effective 
use of natural resources and spatial planning with participation is landscape planning(Marsh 2005; Leitão and Ahern 2002; Termorshuizen et al. 2007; Steiner 2012). Landscape planning has been defined as "forward-looking actions intended for developing, improving or recreating landscapes" in European Landscape Convention (Şahin 2003).In the area where landscape planning will be done, firstly ecological functions and processes should be understood and the interaction between nature and human beings within the landscape should be set forth to support the landscape plans (Uzun and Gültekin 2011; Uzun et al. 2010).According to Hersperger (1994), ecological landscape planning studies aim a precise synthesis of nature and human beings. Consequently, landscape ecology not only pays attention to natural, physical and biological aspects, but it also takes historical, cultural and socio-economic aspects into consideration.

While the purpose of the study was to contribute the development and strengthening of local identity in Ugursuyu and Aksu Watersheds, secure the future of natural and cultural legacy in the area and increase the life quality of local community; "ecotourism" was suggested as the developing factor for improvement potential of the area.

Ecotourism is a journey that involves protection of ecosystem in a respectful manner towards local community(Ross and Wall 1999). (Gültekin and Gültekin 2011; Gültekin and Uzun, 2012; Gültekin and Gültekin 2015; Gültekin et al. 2015; Gültekin et al. 2013; Akova 2006). According to Ziffer (1989), ecotourism is a type of tourism which takes its features from natural history that also includes local cultures. While ecotourism is being organized as an activity, existence of local community should not be neglected. Local community plays a significant role in ensuring that the income received from ecotourism activities makes a high contribution to the district economy and in the achievement of sustainability and many more criteria (Bekiroglu 2008; Gültekin and Gültekin 2012; Uzun et al. 2015; Gültekin et al. 2014; Gültekin et al. 2016). Before deciding on implementation of ecotourism in a rural area, level of enthusiasm among local community and all other stakeholders (private sector-local administration-national administration) to carry out some recreation-tourism activities without damaging natural features.

Regarding the ecosystems within Ugursuyu and Aksu watersheds, which have a total surface area of 639 square kilometers and are located within the boundaries of No.13 Western Black Sea Watershed, fundamental purpose of the study is integrating natural, cultural and social data, forming a landscape plan, taking planning decisions in the scale of $1 / 25.000$ and developing an ecotourism management plan and strategies after planning.

\section{Material and Method}

\subsection{Material}

The borders of the research area are comprised of the drainage basins of Ugursuyu and Aksu streams which are within boundaries of Duzce and Sakarya provinces in West Black Sea Watershed. The whole area consists of $639 \mathrm{~km}^{2} .1 .10000$ scaled Adapazar1 G25 and Adapazar1 G26 coded maps of General Command of Mapping were used while determining the boundaries. In the watersheds of Ugursuyu and Aksu that are situated in the middle of $40^{\circ} 42^{\prime} 20,27^{\prime \prime}$ and $40^{\circ} 37^{\prime} 09,2^{\prime \prime}$ "North 
latitudes and $31^{\circ} 08^{\prime} 16,89^{\prime \prime}$ and $31^{\circ} 13^{\prime} 02^{\prime \prime}$ East latitudes, there are three provinces, fifty villages and one town(Figure 1).

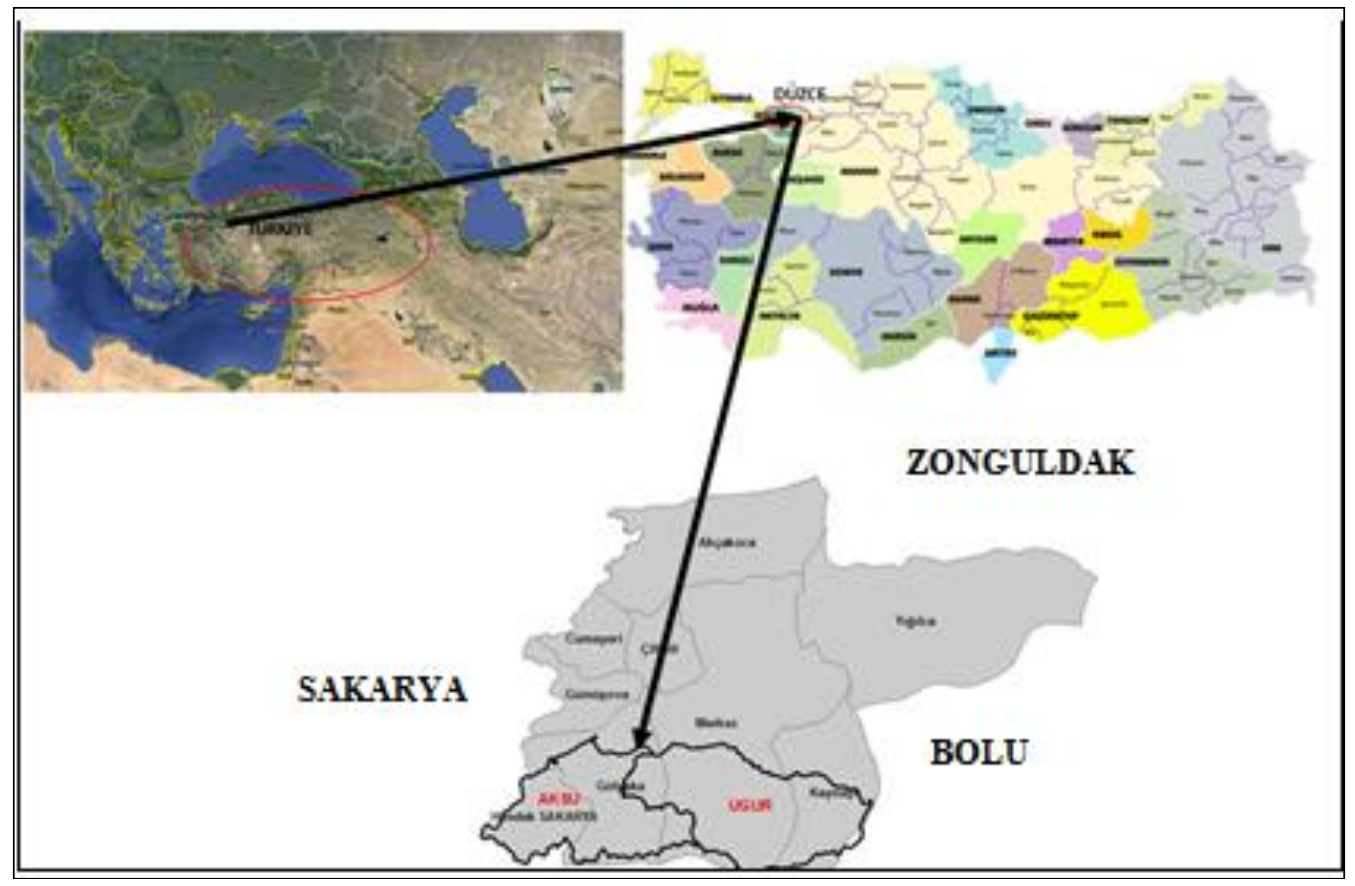

Figure1 Study Area Ugursuyu and Aksu Watersheds

The reasons that Ugursuyu and Aksu Watersheds were chosen as the research area are that the area is rich in natural and cultural landscape values, has recreation possibilities for daily or weekend vacations required by two metropolises like Ankara and Istanbul, holds high ecotourism potential, does not contain ecologically-based spatial planning works, absence of incoordination between the administrative units that handle probable developments and problems that may occur within the area and the human pressure on nature that keeps increasing day by day in Turkey.

\subsection{Method}

The method of study consists of 3 basic stages; Inventory, Analysis and Synthesis.In the inventory stage natural landscape elements (topography, geology, soil, climate, hydrology, flora and fauna etc.)and cultural landscape elements (settlement, tourism resources, roads, festivals etc.) were researched and mapped by using the Arc Map 9.3 program (General Command of Mapping1997, General Directorate of Mineral Research and Exploration 2008, Turkish Statistical Institute 2013).In the second stage of the method, suitability analysis, landscape function analysis and participation analysis were carried out as Ecological, Cultural and Participation (ECP) Method (Figure 2). 


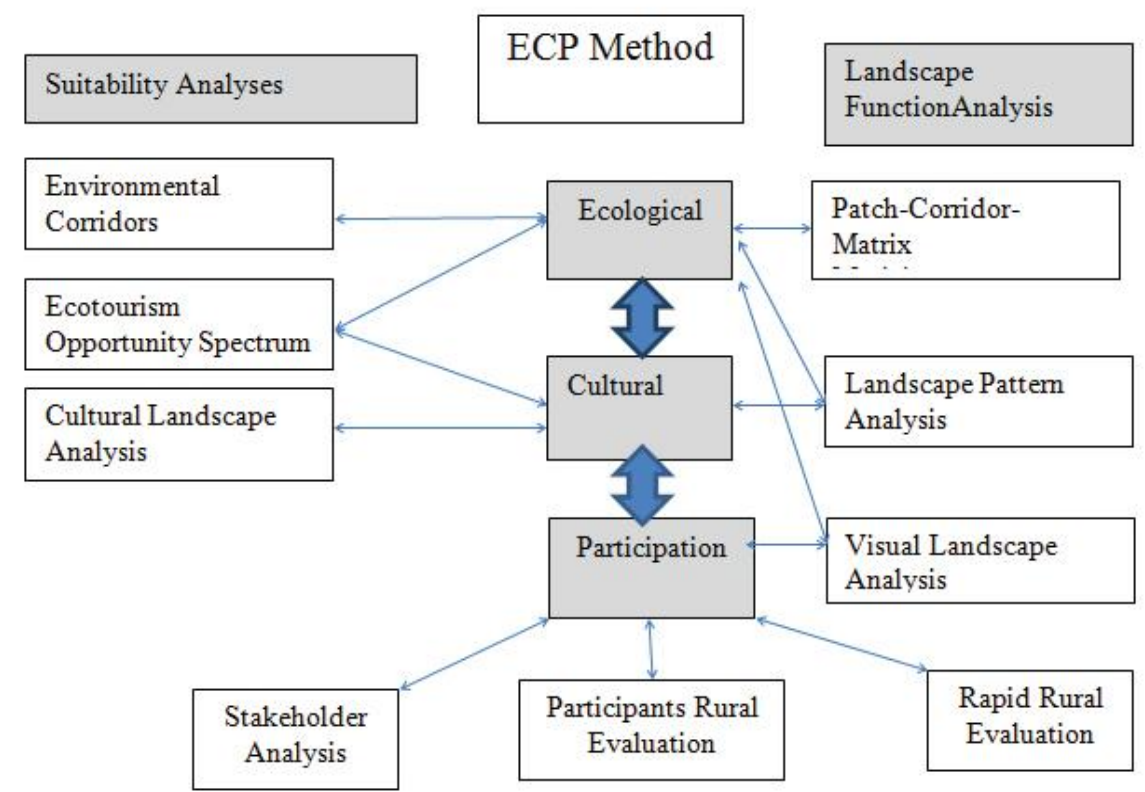

Figure 2. Ecological, Cultural and Participation Method (ECP Method)

Under the title of "Suitability Analyses", a combination of Environmental Corridors Method, ECOS Method, and cultural landscape analysis was used in order to determine the eco-tourism potential of the area and the villages in the area were grouped according to 5 point scale in terms of eco-tourism potential value.

As a final step of the suitability analyses, visual landscape quality assessments were made.As part of this study, a "survey based on visual resource management and user perception" was conducted.

Under the title of "Landscape Functions", structure, function and alteration factors were addressed for ecological assessment of the area and landscape was managed to be brought down to a measurable level by using "patch-corridor-matrix" theory. Thematic maps were created for both watersheds by analyzing satellite images of the area between years of 1999 and 2008. Afterwards, categorical and landscape-level measurements were made by using "Patch Analysis". As part of this process, patch size, number and shape, patch edge and core area index were utilized.

As a result of the use of the method, alteration of landscape pattern over nearly a decade was exhibited.

As a third step of landscape analyses, sociological aspect was addressed under the title of "Participatory Ecotourism Planning". The stakeholders that may participate in the ecotourism planning process were identified; benefits, priorities, behaviors and values of each stakeholder were determined and mutual goals and purposes were established. Through Rapid Rural Appraisal (RRA) method, mukhtars (elected village heads) of the local community were included in the participatory planning process.

In the final step of the method, an eco-tourism management plan was created for Ugursuyu and Aksu watersheds. Landscape plan was created and strategies were 
developed by utilizing all methods together. As to the formation of ecotourism management plan, an enforcement and consultation board was designated and ecotourism development strategies specific to the area were determined.

\section{Results And Discussion}

\subsection{Suitability Analyses}

First of all, Philip Lewis's $(1964,1998)$ environmental corridors technique was used in order to determine the ecotourism potential in the study area. Then ECOS method was applied in order to be able to classify 50 residential areas in the study area in terms of suitability for ecotourism possibilities and to determine the residential areas that were of importance in the development stage of ecotourism strategies.

Classification of main and additional sources can also be made according to spot, linear or polygonal characteristic. Within the scope of the thesis, the areas with more than $\% 30$ inclination were classified as polygonal data, peak points as spot data and streams as linear data. As additional sources, Wild Life Development Area and plateaus were classified as polygonal data, trekking routes as linear data and others as spot data. No spot sources of archaeological quality or of importance were encountered within the area (Figure 3).

Hills and areas with more than 30\%slope were showed as topographic sources; hydrology as surface water and lakes as wetlands on man source map. As to additional sources; trekking areas, picnic areas, plateaus, horse riding areas and clearings within forests were determined as topographic additional sources; waterfalls, trout farms, thermal springs, bird watching towers, wildlife improvement areas and fish habitats as water-based additional sources and festivals and carnivals, health care centers, restaurants, camping areas, schools, important farmer's bazaars, fire watching towers and forest tending houses as historical and cultural sources. When maps of main and additional sources are overlapped, it is seen that there are corridors that extend from Efteni Lake to Aydinpınar and Beyköy towns, Samandere Waterfall to Topuk Pond and Efteni to Güzeldere respectively in Ugursuyu Watershed. Besides, there is another corridor that takes place in both watersheds extends from Beyköy Town to Aydinpinar and Gölyaka counties. This corridor contains quite a lot main and additional source on it. 


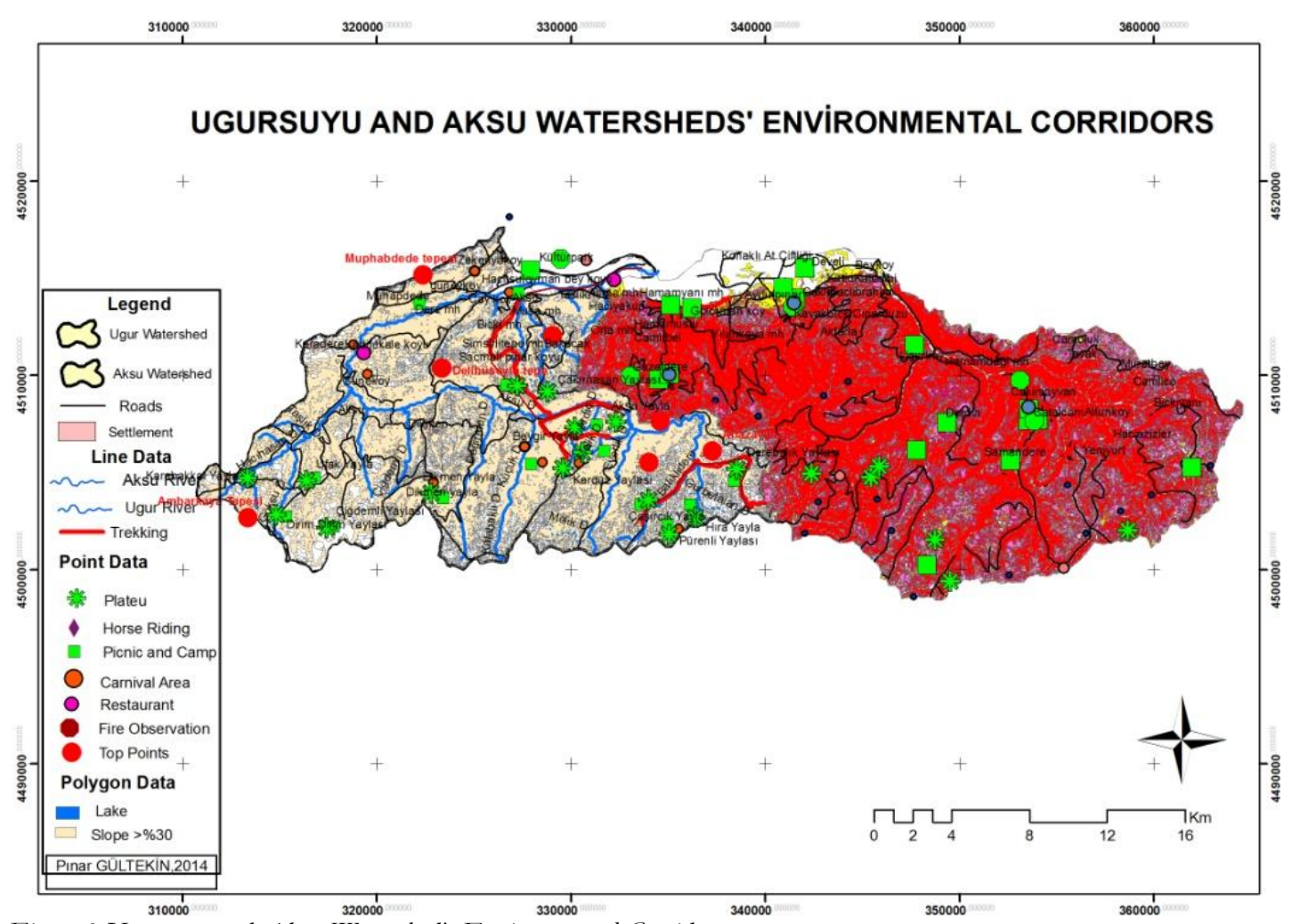

Figure 3 Ugursuyu and Aksu Watershed's Environmental Corridors

In Aksu Watershed, there is a corridor that extends from Aksu Village and goes across Saçmalıpınar Village to Kardüz Plateau and another corridor that contains Derebalık, Hıra and Çaşırcık plateaus. There are main sources and about 30 additional sources that were determined according to environmental corridors method on this corridor.

\subsection{Application of ECOS and Cultural Landscape Analysis Methods}

Ecotourism Opportunity Spectrum (Boyd and Butler 1996; Aciksoz 2010)and Cultural Landscape Analysis(Uzun et al. 2010)methods were used together in order to examine ecotourism opportunities and cultural values in 50 residential areas within the area.

Scoring was conducted for 27 criteria in total, which are topographic structure variety, existence of forests, proximity to Efteni Lake, existence of young population, education status, ecotourism consciousness level, ecotourist accommodation opportunities, transport infrastructure, proximity to central county, infrastructure services, foodbeverage opportunities, current recreational opportunities, vegetative production, animal production, historical importance, elements with historical and archaeological quality, local architecture, handicrafts, religious places, festivals and carnivals, agricultural industry, cooperatives, plateau tradition, education, women's education and monumental objects. 
Ecotourism opportunities were graded as very high, high, medium, low and very low in 5 point scale. 108 being the highest point; residential areas with points between 108 and 81 are interpreted as "having very high ecotourism opportunity"; 80 and 60 as "having high ecotourism opportunity"; 59 and 49 as "having medium ecotourism opportunity"; 48 and 38 as "having low ecotourism opportunity"; 37 and 27 as "having very low ecotourism opportunity".

Aksu Watershed does not contain any villages with "Very High" ecotourism opportunity. Residential areas with "High" ecotourism opportunity are Samandere, Güzeldere, Kavakbıçkı, Gölormanı, Bıçkıyanı, Beyköy, Konaklı and Derdin villages in Ugursuyu Watershed and Aksu, Saçmalıpınar and Hacıüleymanbey villages in Aksu Watershed. Residential areas with "Medium" ecotourism opportunity are Kaledibi, Çakırhacibrahim, Ovapınar, Kuşaçması, Ballıca, Çınarlı, Uğur, Yeniyurt, Hacıazizler, Çatalçam, Çakırsayvan, Çamoluk, Tavak, Aktarla, Duraklar, Çınardüzü and Develi villages in Ugursuyu Watershed and Hamamüstü, Zekeriya, Yunusefendi, Muhabdede, Taşlıkköy, Bakacak, Bekiroğlu, Çamlıbel, Çayköy, Dikmen, Haciyakup and Kadifekale villages in Aksu Watershed. Residential areas with "Low" ecotourism opportunity are Güven, Büyükaçma, Altunköy, Yazlık, İçmeler, Muratbey, Çamlıca and Kutlu villages in Ugursuyu Watershed and Sarıdere village in Aksu Watershed. There are no residential areas classified as having "Very Low" ecotourism opportunity in both watersheds (Figure 4).

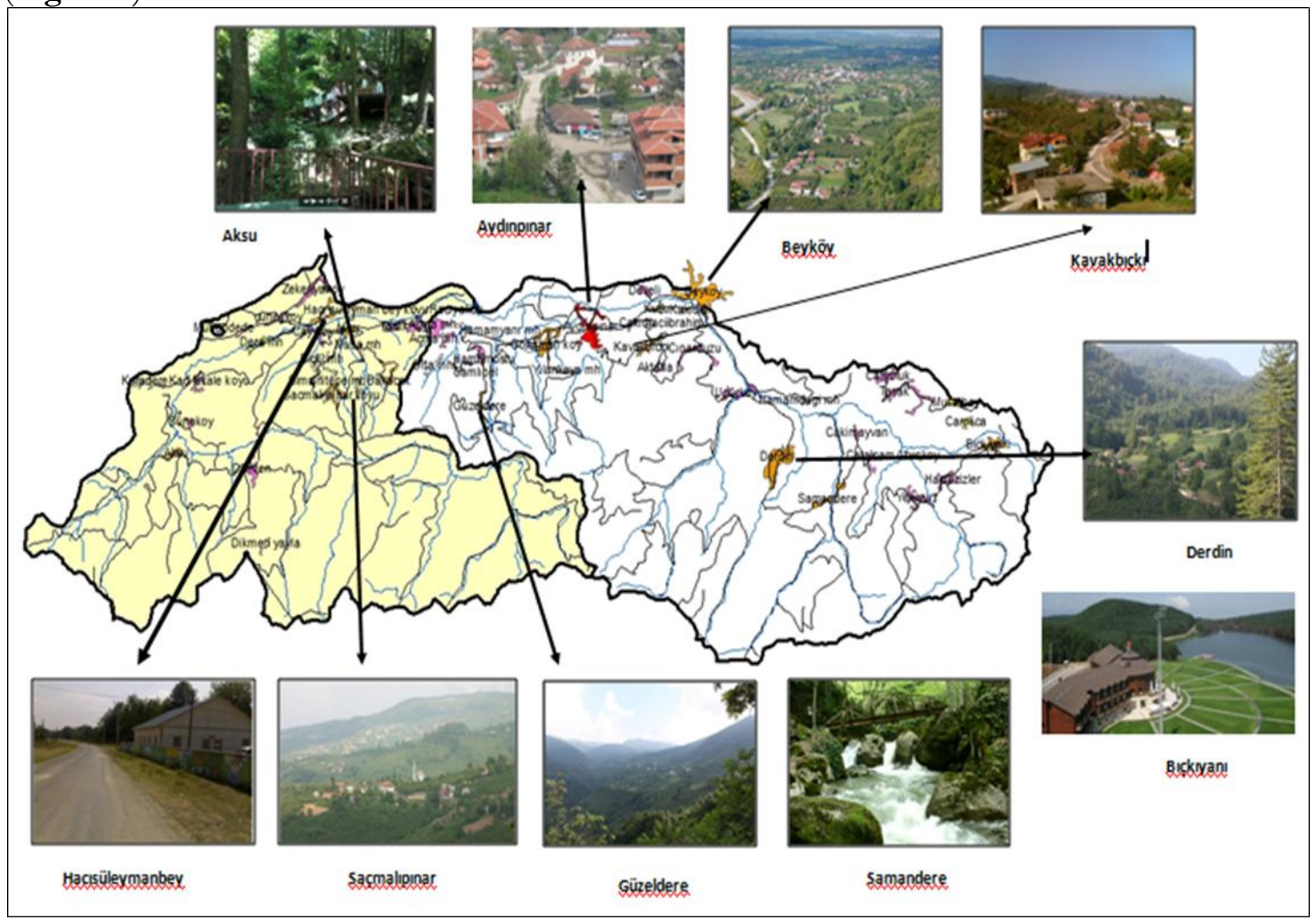

Figure 4. Ugursuyu and Aksu Watersheds' ECOS and Cultural Landscape Analysis Map 


\subsection{Analyses Regarding Visual Landscape Quality}

Analyses were conducted on two levels which were expertise group and user group. Results of both methods were assessed together and strategies for ecotourism were set forth.In the study, coordinates of 174 points were taken. After visibility analyses, it was determined that $65 \%$ of the area was in a visible state.

For determination of visual landscape quality regarding the study area, VQM (Visual Quality Management) model that was developed by USA Bureau of Land Management (BLM, 2010) based on expertise opinion. For each point from which coordinates were taken, observation forms assessing seven factors which were land form, vegetation, water, color, rarity, wide-angle image and cultural changes on a 3-point scale were filled out and explanatory maps for these features were created (Uzun and Müderrisoğlu 2011).Visual quality points for spots were re-calculated for areas through Thiessen polygon method. Upon interpretation of these seven factors under aforementioned assessment criteria, maps were generated for each factor on CBS. Consequently, by overlapping these seven maps, "Visual Landscape Quality" map of Ugursuyu and Aksu watersheds were created (Figure 5).

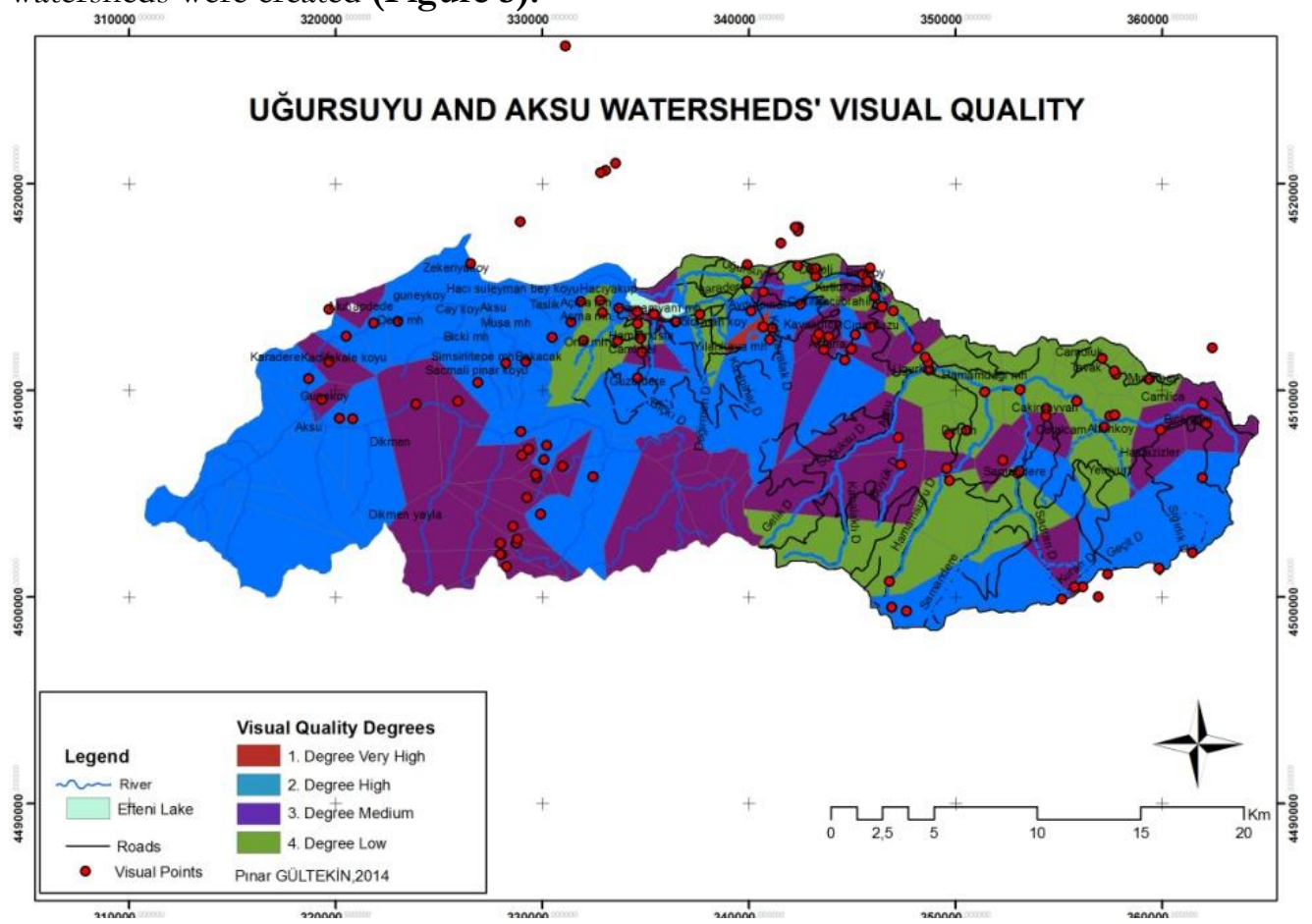

Figure 5.Ugursuyu And Aksu W atersheds' Visual Quality

According to visual landscape quality classification of Aksu Watershed that was obtained as a result of overlapping, areas with $1^{\text {st }}$ Class VLQ cover 3.6\%; $2^{\text {nd }}$ Class VLQ cover $33.8 \%$; $3^{\text {rd }}$ Class VLQ cover $47.6 \%$ and $4^{\text {th }}$ Class VLQ cover $14.5 \%$ of the region. Aksu Watershed contains all four visual landscape quality classes. Areas with highest visual landscape quality are Aksu upper watershed, Kardüz and Dikmen plateau vicinity. 
In the second stage regarding visual quality; a survey was conducted to the tourists in Akçakoca, Karasu, Sapanca and Abant which are a day-trip away from metropolises of Istanbul and Ankara in order to determine opinions of potential ecotourists of Ugursuyu and Aksu watersheds about the area and to establish user requests and expectations. As part of this process, 240 surveys were conducted to the tourists visiting aforementioned sites. 207 of these surveys were deemed valid.

On the front page of the survey, participators were asked the reasons for preferring the related area, type of destination of their preference, whether they had participated in an ecotourism activity before in Duzce, if they had where and what ecotourism activities they had participated in.

On the back page, there were 20 photographs, 13 of which were from Ugursuyu Watershed and seven from Aksu Watershed. Photos were asked to be rated from 1 to 5 in terms of being nice-not nice, interesting-boring, safe-unsafe.

After being informed about the study area and purpose of study briefly and assessing 20 photos of the study area, $93.2 \%$ of the participators stated that they were interested in participating ecotourism activities in Ugursuyu and Aksu watersheds.

Upon assessment of visual preferences of the tourists who participated in the survey; it was clearly observed that they did not prefer images like hydroelectric power stations, construction sites etc. that cause natural damage and that these kind of areas cause tourism sites to lose their attractiveness. In addition, the fact that the tourists have found the photos that includes people safe, that they preferred photos with structures that offer accommodation and activity opportunities, that they did not prefer natural areas without any structure show that tourists want to have infrastructure and superstructure opportunities for their comfort in their destinations. In previous studies, it was indicated that one of the main complaints of the tourists was insufficiency of infrastructure and superstructure.

\subsection{Conducting the Method on Landscape Function Analyses}

Alteration of landscape pattern in Ugursuyu and Aksu watersheds between years of 1999 and 2008 was assessed based on remote perception. Ugursuyu Watershed was divided into seven classes called coniferous forests, mixed forests, broad-leaved forests, open areas, water surfaces, agricultural areas and residential areas. As to Aksu Watershed, it was divided into six classes called coniferous forests, mixed forests, broad-leaved forests, open areas, agricultural areas and residential areas.

Based on land observations and previous studies related to the area, it was decided that the relationship between the components that constitute the structure of landscape in the study area would be best explained by these patch classes.

Studies to determine the alteration of landscape pattern are conducted according to Patch-Corridor-Matrix theory and by considering the habitat function of landscape. After generating thematic maps of stated classes upon analyses of satellite images, patch classes were analyzed separately for each watershed in class and landscape level through various measurements by using Patch analyst 4.0 which is a module operating under Arc GIS 9.3 developed by Rempel in 2010. In the study, assessment was made on two levels: class level and landscape level. It is known for a fact that class level measurements are more efficient in defining ecological processes than landscape level measurements. Landscape 
level measurements were only included in order to exhibit general alteration tendency of the study area (Table1, Table 2).

Table 1.Alteration ratio of land cover/landscape pattern in Ugursuyu Watershed between years of 1999-2008

\begin{tabular}{|c|c|c|c|c|c|c|c|c|c|c|c|c|c|c|}
\hline $\begin{array}{l}\text { Year } \\
\text { s }\end{array}$ & $\begin{array}{l}\begin{array}{l}\text { Conife } \\
\text { rous }\end{array} \\
\text { Forests } \\
\text { (ha) }\end{array}$ & $\%$ & $\begin{array}{l}\text { Mixe } \\
\text { d } \\
\text { Fore } \\
\text { sts } \\
\text { (ha) }\end{array}$ & $\%$ & $\begin{array}{l}\text { Broad- } \\
\text { Leaved } \\
\text { Forest } \\
\text { s (ha) }\end{array}$ & $\%$ & $\begin{array}{l}\text { Ope } \\
\text { n } \\
\text { Area } \\
\text { s } \\
\text { (ha) }\end{array}$ & $\%$ & $\begin{array}{l}\text { Water } \\
\text { Surfac } \\
\text { es } \\
\text { (ha) }\end{array}$ & $\%$ & $\begin{array}{l}\text { Agricu } \\
\text { ltural } \\
\text { Areas } \\
\text { (ha) }\end{array}$ & $\%$ & $\begin{array}{l}\text { Resi } \\
\text { denti } \\
\text { al } \\
\text { Area } \\
\text { s } \\
\text { (ha) }\end{array}$ & $\%$ \\
\hline 1999 & 4540 & \multirow[t]{2}{*}{+137} & 8945 & \multirow[t]{2}{*}{-41} & 6320 & \multirow[t]{2}{*}{-41} & 3300 & \multirow[t]{2}{*}{-8} & 320.29 & \multirow[t]{2}{*}{-97} & 11550 & \multirow[t]{2}{*}{-28} & 423 & \multirow[t]{2}{*}{-6} \\
\hline 2008 & 10791 & & 5270 & & 4206 & & 3013 & & 9,5 & & 8239 & & 394 & \\
\hline
\end{tabular}

Table 2. Alteration ratio of land cover/landscape pattern in Aksu Watershed between years of 1999-2008

\begin{tabular}{|c|c|c|c|c|c|c|c|c|c|c|c|c|}
\hline Years & $\begin{array}{l}\text { Coniferou } \\
\text { s Forests } \\
\text { (ha) }\end{array}$ & $\%$ & $\begin{array}{l}\text { Mix } \\
\text { ed } \\
\text { Fore } \\
\text { st } \\
\text { (ha) }\end{array}$ & $\%$ & $\begin{array}{l}\text { Broad- } \\
\text { Leave } \\
\text { d } \\
\text { Forest } \\
\text { s (ha) } \\
\end{array}$ & $\%$ & $\begin{array}{l}\text { Open } \\
\text { Areas } \\
\text { (ha) }\end{array}$ & $\%$ & $\begin{array}{l}\text { Agricu } \\
\text { ltural } \\
\text { Areas } \\
\text { (ha) }\end{array}$ & $\%$ & $\begin{array}{l}\text { Residen } \\
\text { tial } \\
\text { Areas } \\
\text { (ha) }\end{array}$ & $\%$ \\
\hline 1999 & 10638 & \multirow[t]{2}{*}{-11} & 6047 & \multirow[t]{2}{*}{-5} & 2390 & \multirow[t]{2}{*}{-46} & 1936, & \multirow{2}{*}{$\begin{array}{l}+3 \\
5\end{array}$} & 6434 & \multirow[t]{2}{*}{+11} & 180 & \multirow[t]{2}{*}{+444} \\
\hline 2008 & 9541 & & 5758 & & 1706 & & 2472 & & 7174 & & 986 & \\
\hline
\end{tabular}

When Ugursuyu and Aksu watersheds were compared in terms of alteration in land cover/landscape pattern, it was observed that the amount of residential areas in Aksu Watershed has increased much more than Ugursuyu Watershed (Figure 6). In Aksu Watershed, the amount of residential areas has increased particularly in low elevation, flat or close-to-flat lands around Gölyaka town center. As to Ugursuyu Watershed, it was seen that amount of residential areas have increased around Central County, Beyköy and Ovapinar. It is estimated that since Circassian and Abkhaz populations dominate the villages of Ugursuyu Watershed, general population does not increase much, so the amount of residential areas decreases in the upper watershed. 


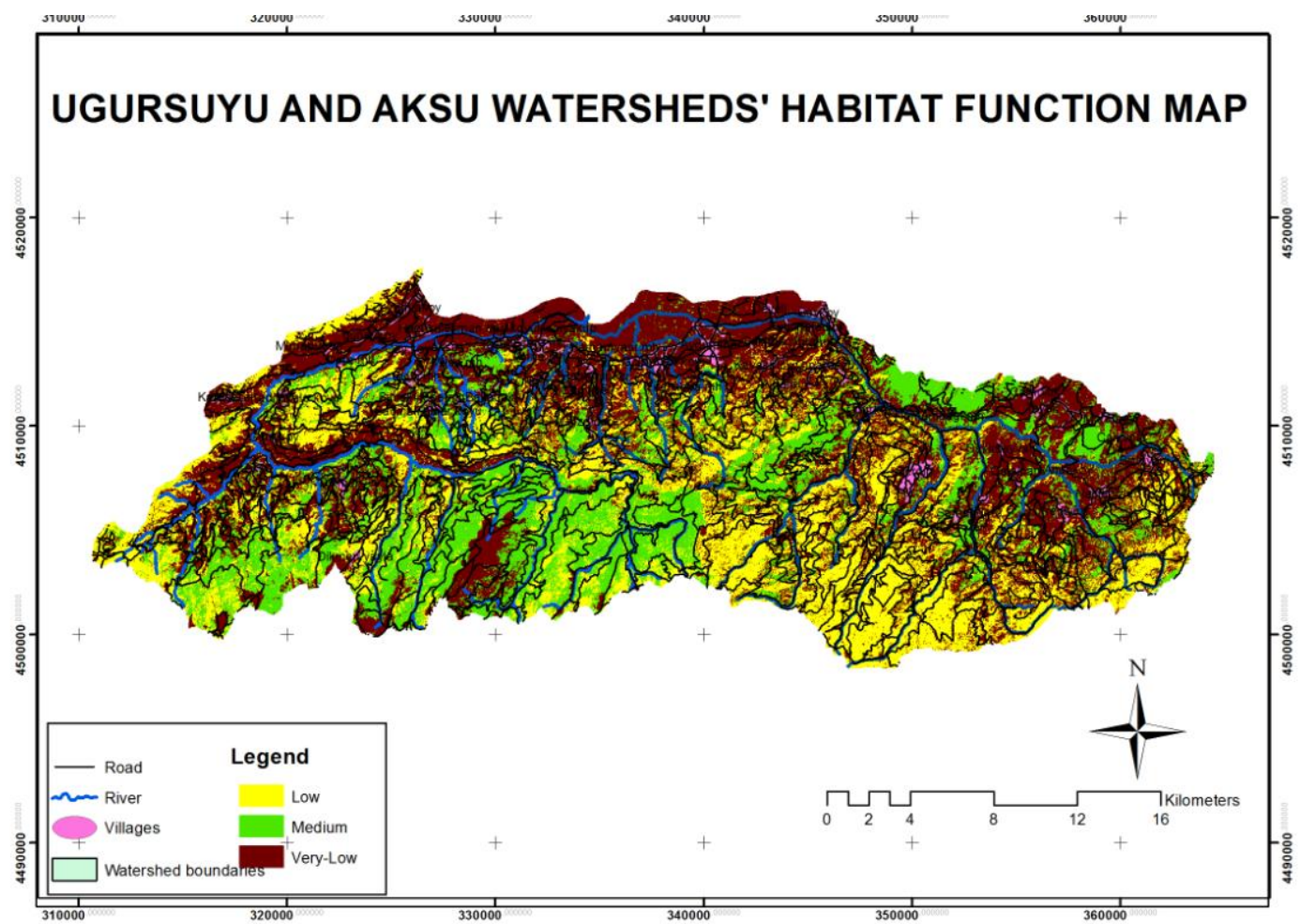

Figure 6.Habitat Function Map of Ugursuyu and Aksu Watersheds

It is estimated that residential areas and buildings have increased in the vicinity of Beyköy due to organized industry. Aksu Watershed has more Black Sea villages than Ugursuyu Watershed. Villages cover a wider area in a scattered manner in the upper watershed. However, since majority of population gather around Gölyaka, residential areas become dense in the lower watershed.

It was also seen that while the amount of coniferous forests has decreased in Aksu Watershed, it has increased in Ugursuyu Watershed. It was determined that the amount of agricultural areas in Ugursuyu Watershed has increased more than Aksu Watershed. It was determined that in both watersheds, there were negative alterations to land cover/landscape pattern within the period which is nearly a decade between 1999 Duzce Earthquake and 2008.

The changes in the forms of land use in these two neighboring watersheds are explained with the cultural identity of local community in the area, executed forestry policies and different morphological structures of the lands.Upon assessment of habitat function analyses in class and landscape levels, it was seen that the form of land use and the actions carried out in the study area between the years of 1999 and 2008 have caused the patches spotted in the land to increase, to shift places and consequently disintegrate the land cover, that the area has a heterogenic landscape mosaic, that the loss of habitat have increased and that there has been ecological disruption in both watersheds. 


\subsection{Participatory Planning Analyses}

In this stage, firstly stakeholder analysis was conducted, benefits, priorities, behaviors and values of each stakeholder were determined and mutual goals and purposes were established. A survey was conducted to 131 ecotourism stakeholders in order to measure "ecotourism perception." A 5-point Likert Scale was used for assessment of expressions about ecotourism perception. Firstly, these expressions were arranged according to an agreement scale between 1: strongly disagree and 5: strongly agree and levels of agreement of to these expressions was tried to be measured. Based on the reliability analysis of the survey, Cronbach's Alpha was determined as 0.94 for 77 expressions. Afterwards, surveys were evaluated through factor analyses.

These factors were named as Strategies for developing ecotourism, Contributions of ecotourism to local community, Obstacles to ecotourism, Interaction between ecotourists and local community, Negative effects of ecotourism on the life style of local community and Ecotourism sources(Table 3).

Table 3. Means and Standard Deviations of Factors

\begin{tabular}{|l|l|l|}
\hline Factor Name & Participation \\
\cline { 2 - 3 } & Arithmetic Means & $\begin{array}{l}\text { Standard } \\
\text { Deviation }\end{array}$ \\
\hline Strategies for developing ecotourism & 3,7221 & 1,419 \\
\hline $\begin{array}{l}\text { Contributions of ecotourism to local } \\
\text { community }\end{array}$ & 3,6163 & 1,36 \\
\hline Obstacles to ecotourism & 3,327 & 1,358 \\
\hline $\begin{array}{l}\text { Interaction between ecotourists and local } \\
\text { community }\end{array}$ & 2,4962 & 1,343 \\
\hline $\begin{array}{l}\text { Negative effects of ecotourism on the life } \\
\text { style of local community }\end{array}$ & 2,180 & 1,186 \\
\hline Ecotourism sources & 2,6565 & 1,2611 \\
\hline
\end{tabular}

Opinions of the stakeholders who participated in the survey can be summarized as below: They think that local community looks optimistically towards the ecotourism activities in Ugursuyu and Aksu watersheds. However, they also think that the local community has not been sufficiently informed about the income-generating aspect of ecotourism, that there are not enough promotional and marketing works about the study area, that there are deficiencies about infrastructure and superstructure in the study area and that all these problems can be worked out through coordinated work of all stakeholders who may participate in ecotourism activities.

\subsection{Developing Landscape Plan and Strategies}

In order to ensure sustainable use of natural resources and minimize the influences of the ecotourism activities considered to be carried out in Ugursuyu and Aksu watersheds, a landscape plan was generated and strategies peculiar to the local area were developed through assessment of suitability analyses and landscape function analyses together. 
First of all, visual and ecological quality maps of the study area were overlapped and visual and ecological features were assessed together. In order to define the areas that have common features and problems, visual and ecological quality maps, land use maps and ecotourism corridors that were obtained through environmental corridors method were all overlapped. Quality assessment was conducted for land use types which are "forests", "residential areas", "tourism", "open areas (pasture)" and "agriculture" in both watersheds. Separate planning decisions were developed for aforementioned land use types. Study area was assessed based on the land use conditions and the visual and ecological quality classification which was made according to PMUI (Physical Mapping Unit Index Based on the criteria of land use types and landscape quality, Ugursuyu and Aksu watersheds were divided into three regions called "Protection-Oriented Landscapes", "Landscapes of Limited Use" and "Landscapes of Controlled Use".

Protection-Oriented Landscapes In Terms Of Landscape Quality

This refers to the areas that possess a rare quality in terms of their natural and visual features and that need to be protected. These are forest areas with very high and high landscape quality and open areas with very high and high landscape quality (Uzun et al. 2010)(Table 4).

Landscapes of Limited Use In Terms Of Landscape Quality

This refers to the areas that are in harmony with their natural features and ecological structure, however open to public in some level, related to protection-oriented landscapes and may constitute buffer zones. These can be forest areas with medium landscape quality, agricultural areas with very high, high or medium landscape quality, open areas with very high, high, medium or low landscape quality and residential areas with very high and high landscape quality (Uzun et al. 2010)(Table 4).

Landscapes of Controlled Use In Terms Of Landscape Quality

This refers to the areas where influences of human activities are felt more than protection-oriented landscapes and landscapes of limited use and where residential, tourism and recreational activities are maintained. These can be residential areas with medium or low landscape quality, forest areas with low landscape quality, tourism areas with low landscape quality and open areas with low landscape quality (Uzun et al. 2010) (Table 4).

Table 4. Protected and used areas in Ugursuyu and Aksu Watersheds

\begin{tabular}{|l|l|l|l|l|}
\hline \multirow{2}{*}{} & \multicolumn{2}{|l|}{ Ugur Watershed } & \multicolumn{2}{l|}{ Aksu Watershed } \\
\cline { 2 - 5 } & Size (Ha) & $\begin{array}{l}\text { Ratio } \\
\mathbf{/ \%}\end{array}$ & Size (Ha) & $\begin{array}{l}\text { Ratio } \\
\mathbf{/ \%})\end{array}$ \\
\hline Protection-Oriented Landscapes & 152.3 & 41.7 & 84.7 & 30.25 \\
\hline Landscapes of Limited Use & 178.7 & 48.9 & 180.5 & 64.2 \\
\hline Landscapes of Controlled Use & 8.5 & 9.4 & 15.3 & 5.6 \\
\hline
\end{tabular}

In the light of all assessments, "Execution and Consultative Board of Ecotourism" was founded in Ugursuyu and Aksu watersheds and it was structured for stakeholders of the study area as stated in Figure 7. 


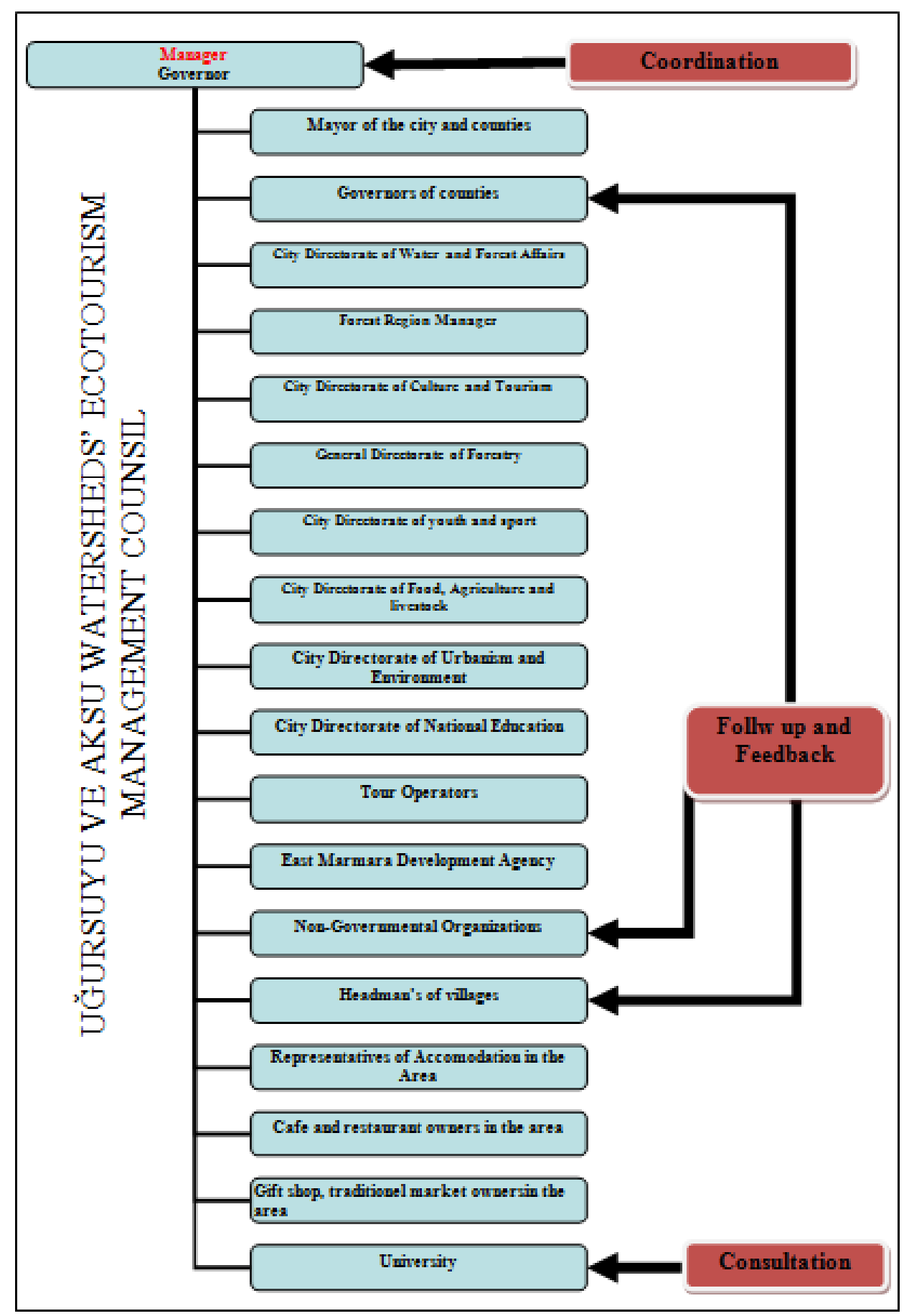

Figure 7. Ecotourism Management Council Model for Uğursuyu and Aksu Watersheds 


\section{Conclusion}

Landscape planning study that was made as part of the research addresses how to execute the planning process in a participatory manner in rural areas and how to assess ecological-based planning study and social data together in the sample of Ugursuyu and Aksu Watersheds. There is not a precedent ecological-based spatial planning study regarding the research area. The fact that population increases in country centers while it decreases in rural areas and disruptions in ecological, cultural and social aspects show that an ecological-based spatial planning study is needed.

In the light of assessments, results and suggestions are as below:

- It is seen that the study area has high ecotourism potential and that particularly Aydınpınar settlement stands out. Beyköy and Bıçkıyanı settlements are other important residential areas that have ecotourism potential.

- However, there are also areas that have low ecotourism potential in the study area. Problems of settlements that qualify as having low ecotourism potential are low number of young population, infrastructure and superstructure deficiencies and low level of ecotourism consciousness. The most important problem of the social life in the study area is the high level of emigration and decline in young population in the settlements. If natural and cultural resources of the area are sufficiently promoted in order to create resources for tourism, young population may be provided with optional sources of income.

- It was observed that the Caucasian and Black Sea communities in the area have reflected their cultural variety on alteration of landscapes. In this context, it was observed that life styles based on ethnic structure, different folkloric elements, traditions and customs, festivals and carnivals held in plateaus and residential areas by support of natural structure and natural protection areas, trekking routes, important exposure points, fishing sites, horse-riding areas and positive values contributed by waterfalls have played an important part on shaping the ecotourism activities in the area.

- It can be deduced that Ugursuyu Watershed is superior to Aksu Watershed in terms of ecotourism potential.

- In addition, run-of-the-river hydraulic power stations built on tributary rivers within the study area cause landslides and visual pollution on the road within the area and along their routes. Borrow pits within the area causes problems in the stream regime and pressure on the ecotourism.

- As a result of ecological-based analyses, it was observed that one of the most important problems that need to be solved in Ugursuyu and Aksu watersheds is rapid structural change and resulting rapid destruction of natural resources. It was determined that particularly in Aksu Watershed, residential areas have increased in a scattered and sectional manner.

- Based on the temporal changes in the area usage, it is necessary to follow the changes that occur in the physical structure of natural landscapes periodically and to evaluate their influences.

- The stakeholders think that local community looks optimistically towards the ecotourism activities in the study area. However, they also think that the local 
community has not been sufficiently informed about the income-generating aspect of ecotourism, that there are not enough promotional and marketing works about the study area, that there are deficiencies about infrastructure and superstructure in the study area and that all these problems can be worked out through coordinated work of all stakeholders who may participate in ecotourism activities.

- $\quad \% 93,2$ of the tourists who constitute a significant stakeholder group stated that they might prefer the study area for ecotourism activities. Cooperation should be made with enterprises that give mass tourism service not only within the study area but in the vicinity of it and activities and service packages that will extend the duration of stay of the incoming tourists should be developed.

- The strategies that were developed for land use types like agriculture, forest, tourism, settlement and pasture provide the related establishments and corporations an opportunity to make location-based decisions about ecotourism activities.

- Landscape plan and approaches created as part of the study will have significant contributions to determination of protection areas, areas of limited use and areas of controlled use in long-term development plans prepared for national parks and nature parks where ecotourism activities are carried out frequently.

As a result, landscape plans or landscape planning approaches for planning and management of ecotourism activities are necessary and should be created in order to take sustainable decisions about natural resources. Besides, as emphasized in European Landscape Convention, landscape planning should be integrated with sectors including ecotourism such as agriculture, housing, industry and forestry. As a study to be based on this one, it is suggested that sub-scale plans be made for residential areas with high ecotourism opportunities in Ugursuyu and Aksu watersheds. Activity planning for various nature sports (trekking, navigation, camping with tents, horse riding, etc.) should be made based on the location choice criteria.

\section{References}

Açıksöz S., Görmüş S. ve Karadeniz N.,(2010).Determination of ecotourism potantial in national parks: Küre Mountains National Park, Kastamonu-Bartın, African Journal of Agricultural Research, Vol. 5 (8), 589-599.

Akova O., Yerel halkın turizmin etkilerini algılamalarına ve tutumlarına yönelik bir araştırma, Akademik İncelemeler Dergisi, Say1:2 Cilt:1, (2006).

Bekiroğlu M (2008).Ecotourism evaluation of natural and culturel characteristics of Uçmakdere, Master's Thesis, Namik Kemal UniversityInstitue of Science, Tekirdag Turkey.

BLM (2010) VRM System. http://www.blm.gov/nstc/VRM/vrmsys.html

Boyd S.W., Butler S.W., (1996) Managing ecotourism: an opportunity spectrum approach, Tourism Management, Vol. 17, No. 8, 557-566.

De Groot, R. S., Alkemade, R., Braat, L., Hein, L., \& Willemen, L. (2010). Challenges in integrating the concept of ecosystem services and values in landscape planning, management and decision making. Ecological Complexity, 7(3), 260-272.

Fung, T., \& Wong, F. K. (2007). Ecotourism planning using multiple criteria evaluation with GIS. Geocarto International, 22(2), 87-105.

General Command of Mapping 1/25000 Topology maps 1997.

Gültekin P, Uzun O., (2012). Determination of Eco-tourism potential of Düzce Ugursuyu and Aksu Basins and Landscape Management. African Journal of Business Management, 6(9), 3428-3437. 
Gültekin P.,Gültekin Y.S., Uzun O. (2016).Stakeholder Analysis and Stakeholder Governance in Participatory Ecotourism Planning for Turkey. 1. International OsmaneliSocial Science Congress, Bilecik.

Gültekin P.,Gültekin Y.S., Uzun, O. (2014).The Relationship between local people and ecotourism in Participatory Planning: Example of Düzce Aydınpınar Village Uluslararası Odundışı Orman Ürünleri Sempozyumu Kahramanmaraș.

Gültekin P.,,Gültekin Y.S., Uzun, O. (2015). Investigation of Conflict Management in Ecotourism in Düzce Uğursuyu and Aksu Basin. IV. Socio- economic problems Congress 29-43.Trabzon.

Gültekin P.,Gültekin Y.S., Uzun, O. (2013). Developing Participatory Ecotourism Perception Scale in Düzce Uğursuyu and Aksu Basins Landscape Architecture V. Congress, Adana.

Gültekin P., Gültekin Y.S. (2011). Ecological Perspective of Natural and Cultural Landscaping Elements Affecting Ecotourism: Example of Gölyaka. Ecology 2011 Symposium, Düzce.

Gültekin Y.S., Gültekin P., (2012). Suggestions on the Protection and Improvement of the Recreational Value of Kabatepe Forest Camp - Caravan and Camping Area. I.Recreation Researches Congress, Antalya.

Gültekin, P., Gültekin Y.S. (2015). Evaluation of Ecotourism Perceptions of Düzce University Forest Faculty Students, Ecology 2015 Symposium, Sinop.

Herrmann, S., \& Osinski, E. (1999). Planning sustainable land use in rural areas at different spatial levels using GIS and modelling tools. Landscape and urban planning, 46(1), 93-101.

Hersperger, A.M. (1994) Landscape ecology and its potential application to planning. Journal of Planning Literature 9: pp. 15-29.

Koschke, L., Fuerst, C., Frank, S., \& Makeschin, F. (2012). A multi-criteria approach for an integrated landcover-based assessment of ecosystem services provision to support landscape planning. Ecological Indicators, 21, 54-66.

Leitão, A. B., \& Ahern, J. (2002). Applying landscape ecological concepts and metrics in sustainable landscape planning. Landscape and urban planning, 59(2), 65-93.

Lewis PH (1964). Quality Corridors for Wisconsin, Landscape Architecture Quarterly, pp. 100-107

Lewis P.,(1998) Environmental corridors land use planning guide, Land Information Bulletin, Technical Paper, No:1.

Marsh, W.M., (1991). Landscape Planning. Environmental Applications, 2nd Edition. Wiley, New York, 340 pp.

MTA 1/25 000 General Directorate of Mineral Research and Exploration Ankara, (2008).

Pickett, S. T., Cadenasso, M. L., Grove, J. M., Nilon, C. H., Pouyat, R. V., Zipperer, W. C., \& Costanza, R. (2008). Urban ecological systems: linking terrestrial ecological, physical, and socioeconomic components of metropolitan areas. In Urban Ecology (pp. 99-122). Springer US.

Rempel R.,Centre for Northern forest ecosystem research (Ontario Ministry of NaturalResources), Lakehead University Campus, Thunder Bay, Ontario. http://flash.lakeheadu.ca/ rrempel/patch/ (Erişim Tarihi: December 2013).

Şahin Ş (2003). European Landscape Convention, Chambers of Landscape Architect, Journal of Landscape Architecture, Number: 1, 52-54, Ankara.

Steiner, F. R. (2012). The living landscape: an ecological approach to landscape planning. Island Press.

Termorshuizen, J. W., Opdam, P., \& Van den Brink, A. (2007). Incorporating ecological sustainability into landscape planning. Landscape and urban planning, 79(3), 374-384.

Tassinari, P., Torreggiani, D., \& Benni, S. (2013). Dealing with agriculture, environment and landscape in spatial planning: a discussion about the Italian case study. Land Use Policy, 30(1), 739-747.

Uzun O, Gültekin P (2011). Process analysis in landscape planning, the example of Sakarya/Kocaali, Turkey, Scientific Research and Essays (SRE). 6(2): 313-331.

Uzun O., Gültekin P., Gültekin Y.S. (2015). Assessment of participatory ecotourism planning and management using by different stages of basin scale. MACODESU 2015, Trabzon.

Uzun O, Müderrisoğlu H (2011). Visual landscape quality in landscape planning: Examples of Kars and Ardahan cities in Turkey, African Journal of Agricultural Research, 6(6), 1627 - 1638.

Uzun O, Dilek F, Çetinkaya G, Erduran F, Açıksöz S (2010). Landscape management, conservation and planning project of Suğla wetland watershed and Bozkır-Seydişehir-AhırlıYalıhüyük counties in Konya province. 1-2 Report. Ministry of Environment and forest, General directorate of nature protection and natural parks. Ankara-Turkey. 
Turkey Statistic Institue 2013 population data

Yu, X. J., \& Ng, C. N. (2007). Spatial and temporal dynamics of urban sprawl along two urban-rural transects: A case study of Guangzhou, China. Landscape and Urban Planning, 79(1), 96-109.

Ziffer, K.,1989, Ecotourism: The Uneasy Alliance, Conservation International, Ernst and Young, Washington DC.

\section{Acknowledgments}

This study was supported by BAP-2012.02.HD.045 numbered Scientific Research Project of Duzce University. It has been converted to the COST project called IS1204 (ToBeWell)" Tourism, Wellbeing and Ecosystem Services". It was also supported by TÜBİTAK 2214/A International Research Fellowship Programme for PhD Students for 6 months. 